\title{
Developed and Produced New Laterite Refractory Brick Samples Protective for Gamma and Neutron Radiation Using GEANT4 Code
}

\author{
GEANT4 Kodunu Kullanarak Gama ve Nötron Radyasyonu için Koruyucu Yeni Laterit \\ Tuğla Örneklerinin Geliştirilmesi ve Üretilmesi
}

\author{
Bünyamin AYGÜN*

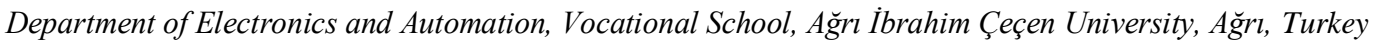

• Geliş tarihi / Received: 29.05.2019 • • Düzeltilerek geliş tarihi / Received in revised form: 10.09.2019 • Kabul tarihi / Accepted: 23.09.2019

\begin{abstract}
In this study, high performance for radiation shielding, new type brick samples have been designed and produced, these containing in different percentages materials such as silicon dioxide, chromium oxide, aluminium oxide, hematite, bismuth oxide, manganese oxide, barium titanate oxide, titanium oxide calcium oxide, nickel oxide, zirconium oxide, lead oxide. Fast neutron shielding parameters, such as total macroscopic cross section effect, mean free path and transmission number have been calculated by using Monte Carlo Simulation Geant 4 code. Neutron absorbed dose experiments have been carried out by using $4.5 \mathrm{MeV}$ energy ${ }^{241} \mathrm{Am}-\mathrm{Be}$ fast neutron source and $\mathrm{BF}_{3}$ gas neutron detector. The obtained results have been compared with paraffin and conventional concrete, to determine the radiation shielding capacity of new brick samples. Some interaction parameters for gamma radiation, such as the mass attenuation coefficient and half-value layer (HVL) have been calculated by using WinXCom software, the results have been compared with conventional and basalt heavy concrete. It is found that, the new type brick samples show good shielding capacity for both neutron and gamma radiation. These new type brick samples can use has been determined for shielding material, in nuclear medicine, in the storage of radioactive waste and nuclear power plants.
\end{abstract}

Keywords: Geant4, Gamma and Neutron, Laterite Brick, Shielding

$\ddot{O} z$

Bu çalışmada, radyasyon zırhlamak için farl yüzdelerde silikon dioksit, krom oksit, alüminyum oksit, hematit, bizmut oksit, mangan oksit, baryum titanat oksit, titanyum oksit kalsiyum oksit gibi malzemeler içeren yüksek performansli yeni tip tuğla numuneleri tasarland ve üretildi. Toplam makroskobik tesir kesit, ortalama serbest yol ve transmisyon saylları gibi hızlı nötron zırhlama parametreleri, Monte Carlo Simulation Geant4 kodu kullanılarak hesaplandı. Nötron soğurma deneyleri $4.5 \mathrm{MeV}$ enerji ${ }^{241} \mathrm{Am}$-Be hizlı nötron kaynağı ve $\mathrm{BF}_{3}$ gazlı nötron dedektörü kullanılarak yapıldl. Yeni tuğla örneklerinin radyasyon kalkanı kapasitesini belirlemek için elde edilen sonuçlar, parafin ve geleneksel beton ile karşılaş̧tııldı. Gama radyasyonu için kütle zayıflatma katsayısı ve yarı değer kalınlı̆̆ (HVL) gibi bazı etkileşim parametreleri WinXCom yazılımı kullanılarak hesapland, sonuçlar geleneksel ve basalt ağır beton ile karşılaştırıldı. Yeni tip tuğla numunelerinin hem nötron hem de gama radyasyonu için iyi zırhlama kapasitesi gösterdiği tespit edildi. Bu yeni tip tuğla numunelerinin, nükleer tıpta, radyoaktif atılartn depolanmasında ve nükleer enerji santrallerinde zırhlama malzemesi olarak kullanılabileceği belirlendi.

Anahtar kelimeler: Geant4, Gama ve Nötron, Laterit Tuğla, Zırhlama

*Bünyamin AYGÜN; baygun35@hotmail.com, Tel: (0505) 82557 26, orcid.org/0000-0002-9384-1540 


\section{Introduction}

Radiation use in many areas, for example, in the agriculture, to mutate seeds for more fertility, to detect water leaks in the dams, in nuclear medicine, diagnosis and treatment of diseases, in industry for material radiography, in the nuclear power plants for energy production (US. NRC, 2017). During these applications, radiation may leak, so protection from radiation is the most important topic to be investigated in nuclear studies. One of the most widely used materials for against emitted radiation is heavy concrete and it has been improved (Singh et al., 2008; Ne ville, 1989). When the radiation interacts with the heavy concrete shield material, high temperature occurs in the material which causes stress and crack on the concrete. This may lead to radiation leaks (Wandschneider et al., 1982). So high temperature resistance is needed for the new shielding materials in the nuclear application. Bricks are the most widely used basic structural materials in the building sector, for its high temperature and corrosion resistant. The brick's main material is natural clay minerals include kaolin and shale (TBPO., 1992). To increase their chemical and heat resistance, different ratios of manganese, barium, chromite, iron oxide, barium carbonate and other additive minerals are added to the structure. These types of refractory brick samples are able to withstand high temperatures at 1800$2000{ }^{\circ} \mathrm{C}$. Bricks can be produced with different content and various mineral to use in radiation shielding. For example, in a study new refractory brick have been produced using high ratio, fly ash and clay for gamma and neutron radiation shielding (Harjinder et al., 2016). In another study, a brick sample designed and produced to be used to store gamma radiation source (van der Graaf et al., 2011). Shielding properties of some brick samples for gamma irradiation have been researched by Awadallah and Imran. It has been reported that gamma ray attenuation coefficient of brick is higher than concrete (Awadallah et al., 2007). Kharitonov developed a new brick sample and performed it at the thermal neutron shielding experiments. It is found that, thermal neutron absorption capacity of new brick samples is greater than graphite which used shielding thermal neutron commonly. (Kharitonov., 2002).

Laterite is a red colored soil with abundant iron and aluminium hydroxide and this is used for making bricks commonly. However, it might be improved with different mineral additives to be used in the radiation shielding study.
In the present paper, four new laterite refractory brick samples with different ratios of $\mathrm{Cr}_{2} \mathrm{O}_{3}$ and other minerals which have high thermal and radiation resistance, have been developed for biological protection at the radiation applications. Total macroscopic cross section $\left(\mathrm{cm}^{-1}\right)$ for neutron radiation, mass attenuation coefficients (MACs), linear attenuation coefficients, mean free path (MFP), half value layer (HVL) values for gamma radiation were theoretically calculated and experimental equivalent dose rate measurements have been carried out for $4.5 \mathrm{Me} \mathrm{V}$ energy, fast neutron radiation.

\section{Materials and Method}

\subsection{Monte Carlo simulation codes Geant4}

Geant4 is a kit that can simulate the interactions of particles and radiation through matter. This kit is used for studies in different areas such as high energy, nuclear and accelerator physics, medicine and space sciences. In addition to, it is also used in tracking, geometry, physics models, electromagnetic, hadronic and optical processes, over a wide energy range from $250 \mathrm{eV}$ to the $\mathrm{TeV}$ energy range (Agostinelli et al 2003). Comprehensive information can be found at www.Geant4.org.

\subsection{Theoretical basis}

Microscopic cross-section $(\sigma)$ refers to the possibility of a neutron particle to interact with a single nucleus, which can be expressed as an equivalent interaction effective area. According to the energy of the neutron, this cross section may vary. The neutron interaction probability with a certain volume of target material depends not only on the microscopic cross section of the individual nuclei, but also on the number of nuclei of target material. Therefore, this interactions probability can be defined the macroscopic cross section $\left(\sum\right)$ (Murray et al., 2014).

$$
N=\frac{\rho}{A} N_{A}
$$

Where, $\mathrm{N}$ atomic density of interaction material $\left(\right.$ atoms $\left./ \mathrm{cm}^{3}\right), \rho$ is the density of interaction material $\left(\mathrm{g} / \mathrm{cm}^{3}\right), \mathrm{N}_{\mathrm{A}}$ is the Avogadro number, $\mathrm{A}$ is the interaction area $\left(\mathrm{cm}^{2}\right)$.

$$
\begin{aligned}
& \sum=\sigma N(1 / \mathrm{cm}) \\
& \sigma t=\sigma \text { scattering }+ \text { - } \text { absorption }=\text { oscattering } \\
& +(\text { ocapture }+\sigma \text { fission }) \\
& \Sigma \text { Total }=\Sigma \text { scattering }+\Sigma \text { absorption }+ \\
& \sum \text { capture }+\sum \text { fission }
\end{aligned}
$$


The transmission is defined neutron numbers which penetrate, passing from the target material. The low number of neutrons indicates that the material has a high neutron capturing capacity. In this paper, to find the number of neutrons passing through the samples, all samples have been interacted with 100000 neutron by using Monte Carlo simulation the Geant 4 code. The obtained results are shown in Table 2.

When mono energetic gamma ray interaction with a material, energy of gamma rays decreases, this is depending on the thickness of the material and according to, the exponentially Lambert Beer law.

$$
I=I_{0} e^{-(\mu / \rho) t}
$$

Where, $I_{0}$ and $I$ are the coming and transmitted energy of photons respectively. $\mu\left(\mathrm{cm}^{-1}\right)$ and $\mu / \rho$ $\left(\mathrm{cm}^{2} \mathrm{~g}^{-1}\right)$ are the linear and mass attenuation coefficients (MACs), $\rho\left(\mathrm{g} . \mathrm{cm}^{-3}\right)$ is the density and $t(\mathrm{~cm})$ is the thickness of the target material.

The mean free path (MFP) is defined, with a target material the radiation interaction properties and this is expressed as the average distance between the two interactions of radiation and this is given as follows:

$$
M F P=\frac{1}{\mu}
$$

Where, $\mu$ is the linear attenuation coefficients of the target materials.

The HVL is a thickness of material require to reduce the coming energy of the gamma ray to its half and it can be defined as follows:

$$
H V L=\frac{\ln (2)}{\mu}=\frac{0.639}{\mu}
$$

The theoretical mass attenuation coefficient, linear attenuation coefficients, half value layer, mean free path has been calculated by using Win XCOM software for gamma radiation of the samples (Gerward et al., 2004).

\subsection{Sample Preparation}

Materials used in production of the laterite refractory brick samples and mixing ratios have been determined by using Monte Carlo simulation Geant 4 code. As shown in Table 1, in the production of samples, materials such as hematite $\left(\mathrm{Fe}_{2} \mathrm{O}_{3}\right)$, Nickel oxide $(\mathrm{NiO})$, aluminium oxide $\left(\mathrm{Al}_{2} \mathrm{O}_{3}\right)$, chrome oxide $\left(\mathrm{Cr}_{2} \mathrm{O}_{3}\right)$, silicon dioxide $\left(\mathrm{SiO}_{2}\right)$, bismuth oxide $\left(\mathrm{Bi}_{2} \mathrm{O}_{3}\right)$, zirconium oxide $\left(\mathrm{ZrO}_{4}\right)$, barium titanate oxide (BaTiO), calcium oxide $(\mathrm{CaO})$ and manganese oxide $(\mathrm{MnO})$ have been used. Determined materials and cement, at the calculated mass ratios with dry powder form was homogeneous mixed with the selected additives. The water has been added and mortar made, this was poured into moulds, air has been removed from the moulds with vibration movement. The moulds have been kept to get rid of at room temperature of 22-24 ${ }^{0} C$. Then produced samples have been kept in throughout at $50{ }^{\circ} \mathrm{C}$ for $12 \mathrm{~h}$, at $100{ }^{\circ} \mathrm{C}$ for $24 \mathrm{~h}$ and at $900{ }^{\circ} \mathrm{C}$, for $2 \mathrm{~h}$ by using laboratory-type electric furnace. Weight loss and thickness changes of the samples have been measured after drying process, thus temperature resistance has been determined. Many simulation trials were carried out by using GEANT4 simulation code to define the mass component ratios of the laterite refractory brick samples and they have been given in Table 1.

\begin{tabular}{|c|c|c|c|c|}
\hline Component & $\begin{array}{c}\text { NLB1 } \\
(\rho=4.62 \\
\left.\mathrm{g} / \mathrm{cm}^{3}\right) \\
\end{array}$ & $\begin{array}{l}\text { NLB2 } \\
(\rho=4.8 \\
\left.\mathrm{g} / \mathrm{cm}^{3}\right)\end{array}$ & $\begin{array}{l}\text { NLB3 } \\
(\rho=3.4 \\
\left.\mathrm{g} / \mathrm{cm}^{3}\right) \\
\end{array}$ & $\begin{array}{l}\text { NLB4 } \\
(\rho=4.1 \\
\left.\mathrm{g} / \mathrm{cm}^{3}\right) \\
\end{array}$ \\
\hline Cement & 10 & 20 & 17 & 17 \\
\hline Water $\left(\mathrm{H}_{2} \mathrm{O}\right)$ & 5 & 10 & 8 & 8 \\
\hline Hematite $\left(\mathrm{Fe}_{2} \mathrm{O}_{3}\right)$ & 58 & 35 & 20 & 40 \\
\hline $\begin{array}{l}\text { Aluminum oxide } \\
\left(\mathrm{Al}_{2} \mathrm{O}_{3}\right)\end{array}$ & 10 & 10 & 15 & 10 \\
\hline $\begin{array}{l}\text { Silicon dioxide } \\
\left(\mathrm{SiO}_{2}\right)\end{array}$ & 5 & 2 & 10 & 5 \\
\hline Nickel oxide (NiO) & - & 5 & - & - \\
\hline $\begin{array}{l}\text { Chrome oxide } \\
\left(\mathrm{Cr}_{2} \mathrm{O}_{3}\right)\end{array}$ & 10 & 15 & 12 & 15 \\
\hline $\begin{array}{l}\text { Bismuth oxide } \\
\left(\mathrm{Bi}_{2} \mathrm{O}_{3}\right)\end{array}$ & 2 & - & - & - \\
\hline $\begin{array}{l}\text { Zirconium oxide } \\
\left(\mathrm{ZrO}_{2}\right)\end{array}$ & - & 3 & - & - \\
\hline $\begin{array}{l}\text { Barium titanate } \\
\text { oxide (BaTiO) }\end{array}$ & - & - & 5 & 5 \\
\hline $\begin{array}{l}\text { Calcium oxide } \\
(\mathrm{CaO})\end{array}$ & - & - & 8 & - \\
\hline $\begin{array}{l}\text { Manganese oxide } \\
\left(\mathrm{MnO}_{2}\right)\end{array}$ & - & - & 5 & - \\
\hline
\end{tabular}

Table 1. Mass combination ratio of new laterite brick samples (\%)

\subsection{Neutron Dose Transmission Experiments}

The properties shown in Table 2, the ${ }^{241} \mathrm{Am} / \mathrm{Be}$ alpha-beryllium neutron source and Canberra NP100B proportional neutron counter have been used for neutron equivalent dose measurements. Firstly, source background $\left(\mathrm{D}_{0}\right)$ has been determined, without the sample between the source and detector. The samples have been placed between the source and detector. After 
measurements, D values have been determined for each sample. Then absorbed dose values have been detected in all samples, by using $\left(\mathrm{Ds}=\mathrm{D}-\mathrm{D}_{0}\right)$ equation. Experimental measurement system is shown in Figure 1 (a-b).

Table 2. Radiation properties of ${ }^{241} \mathrm{Am}-\mathrm{Be}$ neutron source

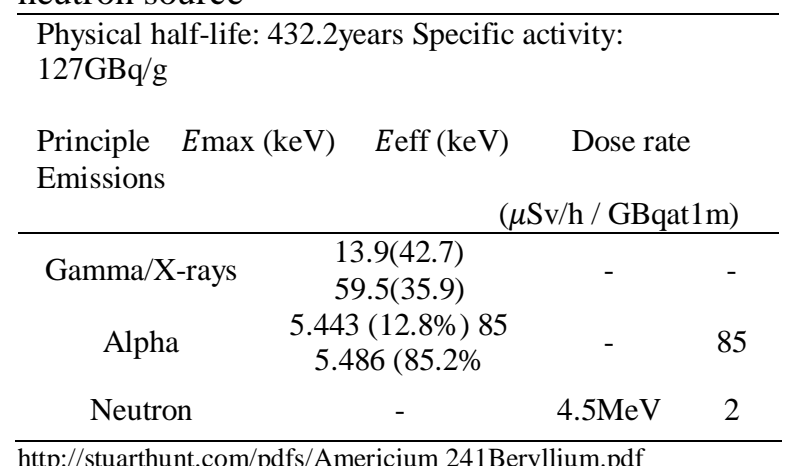

http://stuarthunt.com/pdfs/Americium 241Beryllium.pd

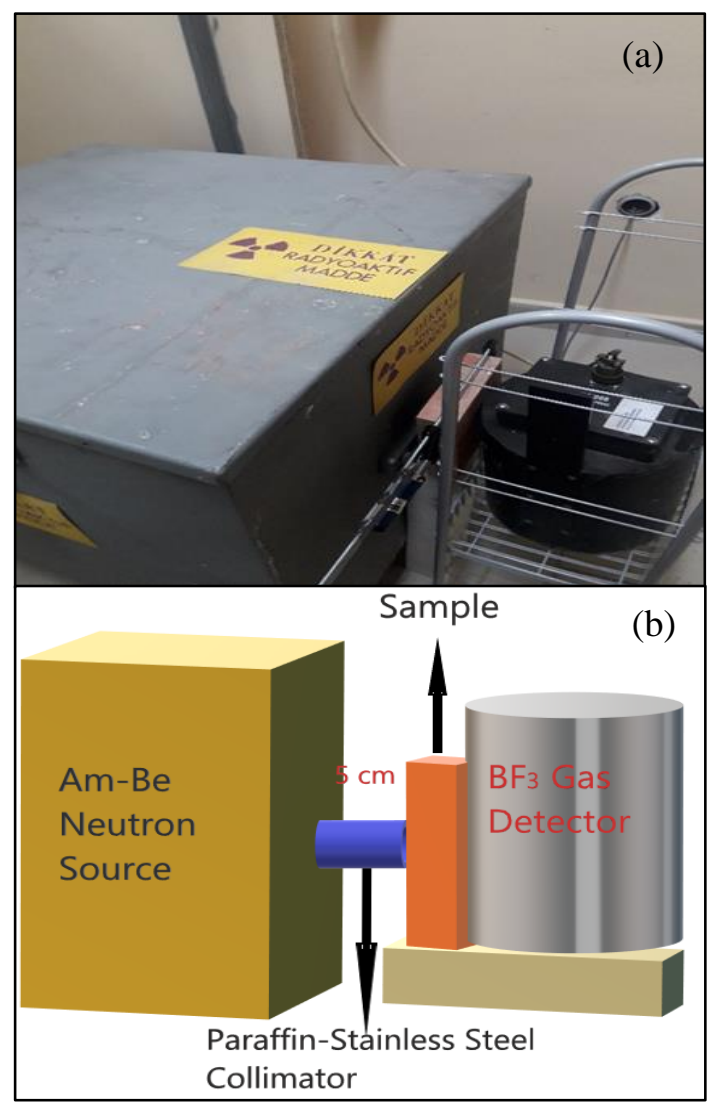

Figure 1. (a-b).Experimental measurement system

\section{Results and Discussion}

In this paper, four different new types of hematite $\left(\mathrm{Fe}_{2} \mathrm{O}_{3}\right)$ based new laterite refractory brick samples are designed and produced; the chemical components are shown in Table 1. Both experimental and theoretically (Total macroscopic cross section, mean free path and transmission numbers) fast neutron shielding parameters have been determined for each sample, by using Monte Carlo simulation Geant 4 code and obtained results have been compared with paraffin and conventional concrete.

Table 3. Mean free path, Transportation values of the samples $4 \mathrm{~cm}$ thick

\begin{tabular}{ccc}
\hline $\begin{array}{c}\text { Sample } \\
\text { code }\end{array}$ & Mean Free Path $(\mathbf{m m})$ & $\begin{array}{c}\text { Transmission } \\
\text { Number }\end{array}$ \\
\hline Paraffin & $1.7223 \pm 0.0135$ & 44014 \\
CC & $1.7783 \pm 0.1429$ & 50662 \\
NLB1 & $1.6945 \pm 0.0136$ & 39031 \\
NLB2 & $1.6553 \pm 0.0125$ & 34158 \\
NLB3 & $1.7141 \pm 0.0113$ & 41801 \\
NLB4 & $1.6852 \pm 0.0132$ & 39240 \\
\hline
\end{tabular}

$N L B$ : New laterite brick, $C C$ : Conventional concrete

Considering at the results of Table 3 , both number of neutrons passing through new materials and mean free path values are low according to reference samples. The lower of these two parameters mean that the neutron absorption forces of the new materials are high.

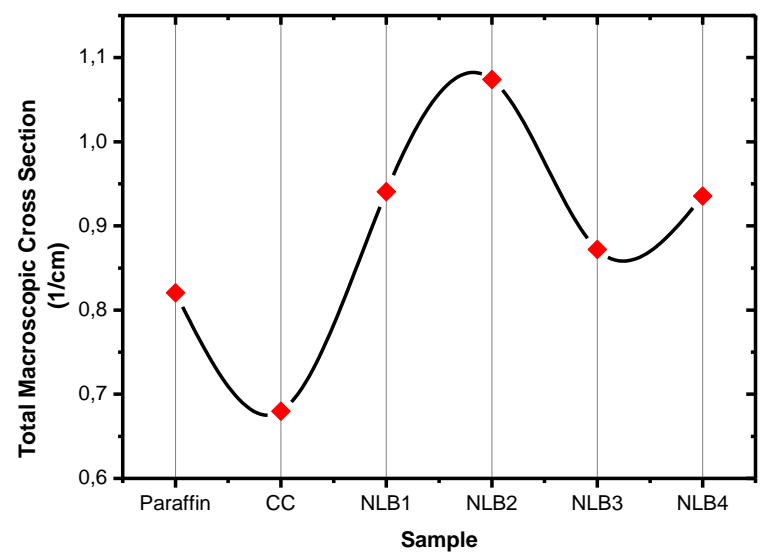

Figure 2. Total Macroscopic Cross Section $\left(\mathrm{cm}^{-1}\right)$

As shown in Fig. 2. Total Macroscopic Cross Sections values of new brick samples are bigger than paraffin and conventional concrete. So new brick materials have high possibility of neutrons interaction. As a result, new brick samples have good moderator ability.

\section{Neutron equivalent absorbed dose measurements}

As shown in Fig. 1 (a-b), the geometrical arrangement of the neutrons, all samples have been placed between the source and detector source, has been exposed to neutron bombardment. The dose values of the samples have been determined and the results have been given in Table 3.

Table 3 clearly shows, absorbed, equivalent dose rates of all new brick samples are bigger than paraffin and conventional concrete. Especially, 
according to others samples NLB 2 sample has high total macroscopic cross section and neutron absorption ability, because this sample is both high bulk density and contains nickel oxide $(\mathrm{NiO})$ and bismuth oxide $\left(\mathrm{Bi}_{2} \mathrm{O}_{3}\right)$ minerals that have big neutron total macroscopic cross section. These results are evidence that all NBL samples possess highest shielding ability better than the paraffin and conventional concrete.

Table 3. Equivalent absorbed dose results

\begin{tabular}{ccc}
\hline Sample & $\begin{array}{c}\text { Equivalent Dose } \\
\text { Rates Absorbed by } \\
\text { Samples }(\boldsymbol{\mu S v} / \mathbf{h})\end{array}$ & $\begin{array}{c}\text { Absorbed Dose Rate } \\
(\%)\end{array}$ \\
\hline Background & 1.2036 & - \\
Paraffin & 0.4815 & $40 \%$ \\
CC & 0.3672 & $30 \%$ \\
NLB1 & 0.7203 & $59 \%$ \\
NLB2 & 0.8048 & $66 \%$ \\
NLB3 & 0.6201 & $51 \%$ \\
NLB4 & 0.7495 & $62 \%$ \\
\hline
\end{tabular}

\section{Gamma-Ray shielding parameter calculations}

Theoretically the most important gamma-ray shielding parameters such as mass attenuation coefficient (MAC), and half value layer (HVL) of the samples have been calculated by using the Beer-Lambert law and Win-XCOM software in the continuous energy range from 0.015 to15 MeV. (Madbouly, et. al., 2016; Berger, et.al., 1987). Obtained results have been compared with conventional concrete and basalt magnetite concrete, as shown in Table 4 and in Figure 3.

According to Table 4 theoretical mass attenuation coefficient values of all NLB are bigger than conventional concrete and basalt magnetite heavy concrete. Furthermore, the MAC values are bigger in the low energy regions, whereas smaller in the high energy regions. These results mostly depend on the chemical compositions of material and the mass component percent ratio of the samples and incoming gamma ray energy. In the low energy region, it can be understand that the MAC values drop, according to the increase in gamma ray energy of all the samples. This situation has been caused by the photoelectric absorption and the effective cross section which inversely proportional to the gamma-ray energy in this region. In the middle energy region (about 1 $\mathrm{MeV}$ ) Compton scattering is dominant, but no sharp decrease occurs in MAC values depending on increasing gamma ray energy. When Table 4 is examined, it is seen that the NLB1 and NLB2 samples have big MAC values for almost all energies compared with other materials. This events may depend on contains a different type mineral concentration of these samples. Also, this clearly shows, the samples of NLB1 and NLB2 have both high effective atomic number and electron, bulk density.

Table 4. Mass attenuation coefficient $\left(\mathrm{cm}^{2} / \mathrm{g}\right)$ values of samples

\begin{tabular}{|c|c|c|c|c|c|c|}
\hline \multicolumn{6}{|c|}{ Mass Attenuation Coefficient (MAC) } & \multirow[b]{2}{*}{ NLB4 } \\
\hline $\begin{array}{c}\text { Energy } \\
(\mathrm{MeV})\end{array}$ & $\mathbf{C C}$ & BMC & NLB1 & NLB2 & NLB3 & \\
\hline 0.015 & 7.054 & 20.575 & 31.343 & 26.423 & 22.621 & 27.415 \\
\hline 0.02 & 3.105 & 9.208 & 14.744 & 12.937 & 10.131 & 12.315 \\
\hline 0.03 & 1.048 & 2.974 & 4.7821 & 4.187 & 3.2738 & 3.970 \\
\hline 0.04 & 0.541 & 1.376 & 2.180 & 1.911 & 2.191 & 2.495 \\
\hline 0.05 & 0.358 & 0.790 & 1.217 & 1.071 & 1.245 & 1.403 \\
\hline 0.06 & 0.275 & 0.526 & 0.779 & 0.691 & 0.805 & 0.897 \\
\hline 0.08 & 0.204 & 0.310 & 0.420 & 0.380 & 0.436 & 0.475 \\
\hline 0.1 & 0.175 & 0.228 & 0.3620 & 0.264 & 0.295 & 0.315 \\
\hline 0.15 & 0.143 & 0.157 & 0.201 & 0.167 & 0.178 & 0.184 \\
\hline 0.2 & 0.127 & 0.132 & 0.151 & 0.136 & 0.141 & 0.143 \\
\hline 0.3 & 0.109 & 0.109 & 0.114 & 0.109 & 0.111 & 0.111 \\
\hline 0.4 & 0.097 & 0.096 & 0.097 & 0.096 & 0.096 & 0.096 \\
\hline 0.5 & 0.088 & 0.087 & 0.087 & 0.086 & 0.087 & 0.086 \\
\hline 0.6 & 0.081 & 0.080 & 0.080 & 0.079 & 0.080 & 0.079 \\
\hline 0.8 & 0.071 & 0.070 & 0.069 & 0.069 & 0.069 & 0.069 \\
\hline 1 & 0.064 & 0.063 & 0.068 & 0.064 & 0.062 & 0.065 \\
\hline 1.5 & 0.052 & 0.051 & 0.050 & 0.051 & 0.051 & 0.050 \\
\hline 2 & 0.045 & 0.044 & 0.043 & 0.044 & 0.044 & 0.043 \\
\hline 3 & 0.037 & 0.037 & 0.036 & 0.036 & 0.036 & 0.036 \\
\hline 4 & 0.030 & 0.031 & 0.032 & 0.032 & 0.032 & 0.032 \\
\hline 5 & 0.029 & 0.030 & 0.031 & 0.030 & 0.030 & 0.030 \\
\hline 6 & 0.027 & 0.028 & 0.028 & 0.028 & 0.028 & 0.028 \\
\hline 8 & 0.024 & 0.026 & 0.027 & 0.026 & 0.026 & 0.026 \\
\hline 10 & 0.023 & 0.025 & 0.026 & 0.025 & 0.025 & 0.025 \\
\hline 15 & 0.021 & 0.024 & 0.025 & 0.025 & 0.024 & 0.025 \\
\hline
\end{tabular}

$C C$ : Conventional concrete, $B M C$ : Basalt magnetite concrete, $N L B$ : New laterite brick

The half-value layer (HVL) indicates, thickness of target material where half of the incident energy has been attenuated. As it is photon energy dependant, increasing the penetrating energy of photons leads to an increase in material's HVL. For four new laterite brick samples between at 0.015-15 MeV photon energies have been calculated, then the results are given in Fig 3. Have been compared with conventional concrete and basalt magnetite heavy concrete.

It has been determined that, the all NLB samples have HVL values smaller than in the conventional concrete and basalt heavy concrete. When a material has small HVL value the material has high gamma ray absorption ability (Ott et al., 1989). These results showed that all new laterite samples have high gamma-ray absorption capacity 
between $0.15-15 \mathrm{MeV}$ energy, according to conventional concrete and basalt heavy concrete.

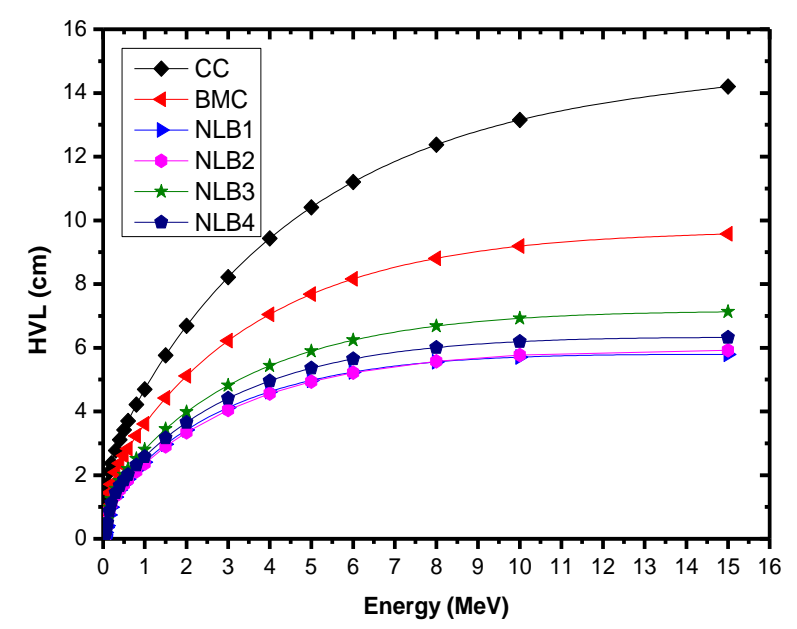

Figure 3. Half value layer at continuous energy range (HVL)

\section{Conclusion}

In this study, high temperature resistant new laterite brick samples have been designed and produced in four different types. For $4.5 \mathrm{MeV}$ fast neutron particles shielding parameters such as total macroscopic cross section, mean free path and transmission number have been calculated theoretically. Furthermore, experimental the equivalent absorbed dose rates have been determined for fast neutron radiation. It has been determined both the total macroscopic cross section, mean free path, transmission number values and absorption ability for fast neutron particles, better than the paraffin and conventional concrete.

Mass attenuation coefficients $(\mathrm{cm} 2 / \mathrm{g})$ and half value layer (HVL) have been calculated all of the samples for the gamma-ray energy range of 0.015 $\mathrm{MeV}$ to $15 \mathrm{MeV}$. All results have been compared with conventional concrete and basalt heavy concrete, it is seen that, all NLB samples have gamma-ray shielding capacity higher than conventional concrete and basalt heavy concrete. Both the experimental and the theory results prove, new laterite brick samples have very superior protection ability for both neutron and gamma radiation applications fields in determining energies. In this study, new shield materials have been developed to advance the field of nuclear technology the availability of these materials has been tested in nuclear applications for radiation safety.

\section{References}

Agostinelli, S. et al., 2003. Geant4 simulation toolkit Nuclear Instruments and Methods in Physics Research A. 506, 250-303.

Awadallah M.I. and Imran, M.M.A., 2007. Experimental investigation of $\gamma$-ray attenuation in Jordanian building materials using Science and Technology of Nuclear Installations 5 HPGe-spectrometer. Journal of Environmental Radioactivity, 94, 129-136.

Berger, M.J. and Hubbell, J.H. 1987. XCOM: Photon Cross Sections Database, NBSIR.

Gerward, G., Guilbert, L., Jensen, N., Leyring, K.B. H., 2004. WinXCom-a program for calculating $\mathrm{X}$-ray attenuation coefficients, Radiat. Phys. Chem., 71-653.

Harjinder, S.M., Gurdarshan, S.B., Kulwinder, S.M. and Gurmel, S.M., 2016. Experimental Investigation of Clay Fly Ash Bricks for Gamma-Ray Shielding, Nuclear Engineering and Technology, 48, 1230-1236.

Kharitonov, V.I., 2002. Radiation shielding bricks from metallurgical products, Industrial Ceramics, 22, 169-174.

Madbouly, A.M. and Atta, E.R., 2016. Comparative Study between Lead Oxide and Lead Nitrate Polymer as Gamma-Radiation Shielding Materials. Journal of Environmental Protection 7, 268-276.

Murray, R.L. and Holbert, K.E., 2014. Nuclear Energy: An Introduction to the Concepts, Systems, and Applications of Nuclear Processes, 7th ed., Elsevier Butterworth-Heinemann.

Neville, A.M., 1989. Properties of Concrete. ELBS.

Ott, K.O., Bezella, W.A., 1989. Introductory Nuclear Reactor Statics. American Nuclear Society, Revised edition ISBN: 0 894, 48033-2.

Singh, K.J., Singh, N., Kaundal, R.S. and Singh, K., 2008. Gamma-ray shielding and structural properties of $\mathrm{PbO}-\mathrm{SiO}_{2}$ glasses. Nuclear Instruments and Methods in Physics Research B 266, 944-948.

TBPO (Trends in Brick Plant Operations), 1992. The American Ceramic Society Bulletin. pp. 69-74.

USNRC (United States Nuclear Regulatory Commission), 2017. Uses of Radiation.

van der Graaf, E.R., Limburg, J., Koomans, R.L. and Tijs, M., 2011. Monte Carlo based calibration of scintillation detectors for laboratory and in situ gamma ray measurements. Journal of Environmental Radioactivity, 102, 270-282.

Wandschneider, R. and Pick, R., 1982. Ver Concrete, Masonry, Screed and Plaster, Radiation Protection Techniques Concrete Information Verlag, 22, 47-50. 